\title{
Long-Term Alterations in Growth Hormone and Insulin Secretion after Temporary Dietary Protein Restriction in Early Life in the Rat
}

\author{
ZEEV HAREL AND GLORIA SHAFFER TANNENBAUM \\ Departments of Pediatrics, Neurology and Neurosurgery, McGill University and the Neuropeptide \\ Physiology Laboratory, McGill University-Montreal Children's Hospital Research Institute, \\ Montreal, Quebec H3H 1P3, Canada
}

\section{ABSIRACT}

Protein malnutrition early in life stunts subsequent physical growth in both humans and rats, but the mechanism(s) is unknown. To test the hypothesis that temporary early life dietary protein restriction produces long-term alterations in the growth hormone $(\mathrm{GH})$ neuroendocrine axis, we examined the effects of $3 \mathrm{wk}$ of exposure to dietary protein restriction in male rats postweaning (3-6 wk of age) on spontaneous and GH-releasing factor (GRF)-stimulated $\mathrm{GH}$ secretion at $12 \mathrm{wk}$ of age. In comparison to rats weaned onto a normal diet (23\% protein), rats weaned onto a low (4\%) protein diet failed to catch up growth when transferred to the normal diet between 6 and $12 \mathrm{wk}$ of age. Spontaneous 6-h GH secretory profiles of adult rats fed the low protein diet early in life showed a $41 \%$ reduction in mean GH peak amplitude and a significant suppression in overall mean 6-h plasma GH concentrations $(37.5 \pm 4.5$ versus $56.9 \pm 5.9 \mu \mathrm{g} / \mathrm{L}$; $p<0.02$ ). The magnitude of the $\mathrm{GH}$ response to $1 \mu \mathrm{g}$ of rat GRF(1-29) $\mathrm{NH}_{2}$ i.v. challenge was augmented during the $\mathrm{GH}$ trough period in these rats $(165.7 \pm 30.4$ versus $43.9 \pm 17.6$ $\mu \mathrm{g} / \mathrm{L} ; p<0.01)$. Although basal plasma IGF-I levels and glucose tolerance of protein-deprived rats were normal at $12 \mathrm{wk}$ of age, the insulin response to ip glucose was severely blunted [insulin integrated area under the curve: $303.0 \pm 32.7$ versus $778.3 \pm$ $105.0 \mathrm{pmol} / \mathrm{L} / 75 \mathrm{~min} ; p<0.01]$. These results demonstrate that temporary protein malnutrition early in life 1 ) blunts spontaneous pulsatile $\mathrm{GH}$ secretion, 2) augments $\mathrm{GH}$ responsiveness to GRF challenge, and 3) reduces the insulin secretory response to glucose in adulthood. Our findings suggest that dietary protein in early life is an important determinant for $\mathrm{CNS}$ control of $\mathrm{GH}$ secretion as well as for the development of pancreatic $\beta$-cell sensitivity to glucose. Such alterations in the GH neuroendocrine axis, together with the subnormal insulin secretion, likely contribute to the lack of catch-up growth in this model. (Pediatr Res 38: 747-753, 1995)

Abbreviations
GR, growth hormone
SRIF, somatostatin
SLI, somatostatin-like immunoreactivity
IRI, immunoreactive insulin
AUC, area under the curve

GH, growth hormone

GRF, growth hormone-releasing factor

SRIF, somatostatin

IRI, immunoreactive insulin

AUC, area under the curve
Undernutrition in early life impairs subsequent physical growth in both humans (1-4) and rats (5), but the mechanism(s) is not yet known. Exposure to early postnatal undernutrition, in general, and protein malnutrition, in particular, has deleterious effects on the development and function of various organs, and leads to lower protein/DNA ratios in several tissues (5-10). Such persisting cellular hypoplasia may result in insufficient cellular machinery for hormonal biosynthesis.

Received February 23, 1995; accepted June 29, 1995

Correspondence and requests for reprints: Gloria S. Tannenbaum, Ph.D., Neuropeptide Physiology Laboratory, McGill University-Montreal Children's Hospital Research Institute, 2300 Tupper Street, Montreal, Quebec H3H 1P3, Canada.

Supported by Grant MT-6837 (to G.S.T.) from the Medical Research Council of Canada. Z.H. was the recipient of a Postdoctoral Research Fellowship from the McGill University-Montreal Children's Hospital Research Institute. G.S.T. is a Chercheur de Carrière of the Fonds de la Recherche en Santé du Québec.

Presented in part at the Annual Meeting of the Society for Pediatric Research, Seattle, WA, 1994.
GH and insulin are important growth-promoting hormones which exhibit interrelated metabolic actions. In the rat, a limited period of protein malnutrition early in life results in a persistent impairment in the insulin secretory response to glucose (5), a decreased $\beta$-cell mass (11), and an increased peripheral sensitivity to insulin (12). In general, GH shares protein anabolic properties with insulin but counteracts the effects of insulin on glucose and lipid metabolism (13). The elevation in $\mathrm{GH}$ levels that occurs during pubertal acceleration of linear growth in the human leads to reduced peripheral sensitivity to insulin accompanied by a compensatory increase in glucose-stimulated insulin secretion (13), whereas GHdeficient patients are hypersensitive to the actions of insulin (14). Moreover, it has been suggested that the production of IGF-I, an important mediator of GH's action on peripheral tissues, is negatively affected by early life protein-energy 
malnutrition, preventing it from reaching the supranormal levels usually associated with compensatory or catch-up growth in the rat (15).

We have recently reported that short-term dietary protein restriction in the adult rat impairs spontaneous pulsatile $\mathrm{GH}$ secretion and have suggested that the blunted $\mathrm{GH}$ release may contribute to the growth retardation observed in this model (16). To date, there are no studies that have investigated the effects of temporary exposure to protein malnutrition in early life on the $\mathrm{GH}$ neuroendocrine axis in adulthood. In this context, it was tempting to speculate that alterations in $\mathrm{GH}$ secretion might account for both the growth deficits as well as some of the long-term consequences on carbohydrate metabolism characteristic of early life temporary protein restriction. To test this hypothesis, we examined the effects of $3 \mathrm{wk}$ of exposure to dietary protein restriction in male rats postweaning on spontaneous GH, insulin, IGF-I, and glucose secretion at 12 wk of age.

\section{METHODS}

Animals and experimental procedure. Twenty-four male Sprague-Dawley pups and their lactating mothers were obtained from Charles River Canada (St. Constant, Quebec, Canada). Upon arrival, the rats were housed on a 12-h light, 12-h dark cycle (lights on between 0600 and $1800 \mathrm{~h}$ ) in a temperature $\left(22 \pm 1^{\circ} \mathrm{C}\right)$ - and humidity-controlled room. Free access to regular Purina rat chow (Ralston-Purina, St. Louis, $\mathrm{MO})$ and tap water was given throughout lactation. At $3 \mathrm{wk}$ of age, the young rats were weighed and caged in groups of six, evenly matched for body weight. Twelve young rats (control group) were weaned onto the regular diet which consisted of $23 \%$ protein, $59 \%$ carbohydrates, $5 \%$ fat, $8 \%$ nonnutritive bulk, $1 \%$ vitamins, and $4 \%$ minerals, hereafter referred to as the normal diet. Twelve other rats (experimental group) were weaned onto a low protein isocaloric pelleted diet (ICN Biochemicals, Cleveland, $\mathrm{OH}$ ) with the following composition: $4 \%$ protein, $78 \%$ carbohydrates, $5 \%$ fat, $8 \%$ nonnutritive bulk, supplemented with $1 \%$ vitamins and $4 \%$ minerals. The two diets were given ad libitum for 3 wk, and both groups of animals were raised under identical environmental conditions. At $6 \mathrm{wk}$ of age, rats fed the low protein diet were transferred to the normal diet, and both groups of rats continued to consume the normal diet until the end of the experiment, at 12 wk of age. All animals were weighed weekly until 9-10 wk of age. At this age, both groups of rats were implanted with chronic intracardiac venous cannulae under sodium pentobarbital $(50 \mathrm{mg} / \mathrm{kg}$, intraperitoneally) anesthesia, using a previously described technique (17). After surgery, the animals were placed directly in isolation test chambers and given free access to regular Purina rat chow and tap water until their body weights returned to preoperative levels (approximately $1 \mathrm{wk}$ ). During this time, and thereafter, the rats were weighed and handled daily. Between 11 and 12 wk of age, a series of experiments were carried out. All animal-based procedures were approved by the McGill University Animal Care Committee.
On the day of each experiment, food was removed $1.5-2 \mathrm{~h}$ before the start of sampling and returned at the end. Blood samples $(0.4 \mathrm{~mL})$ were withdrawn every $15 \mathrm{~min}$ for periods of $6 \mathrm{~h}(1000-1600 \mathrm{~h})$ from all rats. All blood samples were immediately centrifuged and the plasma separated and stored at $-20^{\circ} \mathrm{C}$ for subsequent measurement of $\mathrm{GH}$. The red blood cells were resuspended in isotonic saline and returned to the animal after removal of the next blood sample to prevent hemodynamic instability.

In the first experiment, we assessed the effects of early life exposure to the $4 \%$ protein diet on spontaneous pulsatile $\mathrm{GH}$ secretion and basal plasma IGF-I concentrations during adult life. Six-hour plasma profiles were obtained from five rats of the experimental group and from five rats of the control group.

In the second experiment, we examined the long term effects of early dietary protein restriction on pituitary $\mathrm{GH}$ responsiveness to GRF. Five rats from the experimental group and five rats from the control group were administered rat GRF(129) $\mathrm{NH}_{2}$ i.v. at two different time points during the 6-h sampling period. The times of 1100 and $1300 \mathrm{~h}$ were chosen because these reflect typical peak and trough periods of $\mathrm{GH}$ secretion, respectively, as previously documented in this laboratory $(17,18)$. The GRF peptide (lot CH-23-25-31-10-16; kindly provided by Dr. P. Brazeau, Notre-Dame Hospital, Montreal, Canada) was diluted in normal saline just before use and administered at a concentration of $1 \mu \mathrm{g} / 0.3 \mathrm{~mL}$. To document the rapidity of the $\mathrm{GH}$ response to GRF, an additional blood sample was obtained 5 min after each injection of the peptide.

In the third experiment, we investigated the glucose tolerance and insulin secretory response to glucose challenge. Rats from both groups were fasted overnight $(15-17 \mathrm{~h}$ before the test). On the test day, basal blood samples $(0.4 \mathrm{~mL})$ were drawn every 15 min between 1030 and 1130 h. At 1130 h, rats of both groups were injected intraperitoneally with a $50 \%$ (wt/vol) glucose solution at a dose of $2 \mathrm{~g}$ of glucose $/ \mathrm{kg}$ of body weight. Blood samples were obtained every $15 \mathrm{~min}$ for an additional 3-h period (1130-1430 h) after the injection, for subsequent measurement of glucose and insulin.

At 12 wk of age, both groups of rats were killed by rapid decapitation. The pituitary gland was removed, weighed, homogenized in $2 \mathrm{~mL} 0.05 \mathrm{M} \mathrm{NaHCO}-\mathrm{Na}_{2} \mathrm{CO}_{3}$ buffer, $\mathrm{pH} 9.6$, and centrifuged at $2000 \times \mathrm{g}$ for $30 \mathrm{~min}$. The supernatant was removed and stored at $-20^{\circ} \mathrm{C}$ until subsequent assay for $\mathrm{GH}$. Portions of the pancreas (body and tail) were also quickly removed onto dry ice and weighed. Individual fragments were added to $2 \mathrm{~mL}$ of $2 \mathrm{~N}$ acetic acid, placed in a boiling water bath for $5 \mathrm{~min}$ to inactivate degradative enzymes, homogenized, and then centrifuged at $2000 \times g$ for $30 \mathrm{~min}$. The supernatant was removed and frozen at $-20^{\circ} \mathrm{C}$ until subsequent assay for insulin and somatostatin.

Hormone assays. Plasma GH concentrations were measured in duplicate by double antibody RIA using materials supplied by the National Institute of Diabetes and Digestive and Kidney Diseases (NIDDK) Hormone Distribution Program (Bethesda, $\mathrm{MD}$ ). The averaged plasma $\mathrm{GH}$ values are reported in terms of the $\mathrm{GH}$ reference preparation (rGH-RP-2). The standard curve was linear between 0.62 and $320 \mu \mathrm{g} / \mathrm{L}$. All samples with values 
above $320 \mu \mathrm{g} / \mathrm{L}$ were reassayed at dilutions ranging from 1:2 to $1: 10$. The intra- and interassay coefficients of variation were 7.6 and $9.6 \%$, respectively, for duplicate samples of pooled plasma containing a mean $\mathrm{GH}$ concentration of $7.4 \mu \mathrm{g} / \mathrm{L}$.

Plasma IGF-I concentrations were measured in duplicate by double antibody RIA using a modification of previously described methods $(19,20)$. To decrease the interference of IGF binding proteins in the assay, the samples were prepared by acid-ethanol extraction followed by cryoprecipitation. In brief, $200 \mu \mathrm{L}$ of an acid ethanol solution [87.5\% ethanol and $12.5 \%$ $2 \mathrm{~N} \mathrm{HCl}(\mathrm{v} / \mathrm{v})]$ was added to $50 \mu \mathrm{L}$ plasma. After incubation for $30 \mathrm{~min}$ and centrifugation, $100 \mu \mathrm{L}$ of supernatant was neutralized with $40 \mu \mathrm{L}$ of $0.855 \mathrm{M}$ Tris and kept at $-20^{\circ} \mathrm{C}$ for $1 \mathrm{~h}$. After cryoprecipitation and recentrifugation, the supernatant was further diluted 1:40 in a buffer containing $0.9 \% \mathrm{NaCl}$, the acid-ethanol solution, and 0.855 Tris-base $(1: 4: 2 \mathrm{v} / \mathrm{v})$. The RIA was performed in a buffer ( $\mathrm{pH} 7.5)$ containing $200 \mathrm{mg} / \mathrm{L}$ protamine sulfate, $4.14 \mathrm{~g} / \mathrm{L}$ sodium phosphate monosodic, 0.2 $\mathrm{g} / \mathrm{L}$ sodium azide, $3.72 \mathrm{~g} / \mathrm{L}$ EDTA, and $0.25 \%$ ultrapure BSA (A-4378; Sigma Chemical Co., St. Louis, MO). The IGF-I/ SmC rabbit antiserum (UB3-189) was obtained from the NIDDK Hormone Distribution Program (gift of Drs. L. Underwood and J. Van Wyk). Recombinant human IGF-I (Lilly, Indianapolis, IN) was iodinated by the chloramine-T method. The averaged IGF-I values are reported in terms of the recombinant human IGF-I reference preparation (Lilly) that was used for the standard curve of the assay. The standard curve was linear between 0.1 and $25 \mu \mathrm{g} / \mathrm{L}$. All samples were run in a single assay.

IRI was measured by a dextran-coated charcoal method using guinea pig anti-porcine insulin serum (21). Purified crystalline rat insulin (Lot. 615-JE 6-9; Lilly, kindly provided by Dr. R. Chance) served as a reference standard. The sensitivity of the assay was $27.5 \mathrm{pmol} / \mathrm{L}$, and the intra- and interassay coefficients of variation were 8.2 and $10.3 \%$, respectively, for duplicate samples of pooled plasma containing a mean IRI concentration of $976.3 \mathrm{pmol} / \mathrm{L}$. Plasma glucose was measured by an automated glucose oxidase method (Glucose Analyzer 2, Beckman Instruments, Palo Alto, CA).

SLI was assayed by a previously reported double antibody RIA (22). On the day of the assay, the pancreatic samples were recentrifuged at $900 \times g$ for $10 \mathrm{~min}$ and then diluted at concentrations ranging from 1:100 to $1: 200$ and neutralized with $5 \mathrm{~N} \mathrm{NaOH}$ using phenol red as a $\mathrm{pH}$ indicator. The SLI values are reported in terms of the somatostatin-14 reference standard (lot 83-57-36-60-70; kindly provided by Dr. N. Ling, Salk Institute, La Jolla, CA). The intra- and interassay coefficients of variation were 8 and $12 \%$, respectively.

Statistical analysis. The plasma GH profiles of individual rats were analyzed using the Cluster Analysis Program for endocrine pulse detection (23). Briefly, a $t$ statistic of 4.1 was selected to maintain a maximal false-positive rate of $1 \%$ or less by using test cluster sizes of one in the prepeak nadir, peak, and postpeak nadir. Analysis of variance and $t$ tests for unpaired and paired data, as appropriate, were used for statistical comparisons between and within experimental groups. The integrated area under the insulin and glucose response curves was calculated using the linear trapezoidal method. The results are expressed as the mean \pm SE. $p<0.05$ was considered significant.

\section{RESULTS}

Body weight gain. At weaning (3 wk of age), rats of the experimental group weighed $41.5 \pm 0.5 \mathrm{~g}$ compared with 41.0 $\pm 0.8 \mathrm{~g}$ for the control group. After weaning, rats fed the normal diet continued to gain weight throughout the experimental period, with a mean body weight gain of $139.1 \pm 3.2 \mathrm{~g}$ over the 3 -wk period. In contrast, rats weaned onto the $4 \%$ protein diet (experimental group) gained almost no weight from weaning to $6 \mathrm{wk}$ of age $(4.2 \pm 0.7 \mathrm{~g} ; p<0.001)$ (Fig 1). When transferred to the normal control diet, these rats immediately resumed growing and gained weight at a rate similar to that of the control group (Fig. 1); however, they remained significantly smaller than the control rats throughout the $6-12$-wk period and never caught up in weight to the control group. (Final weight: $314.3 \pm 5.6$ versus $421.7 \pm 6.5 \mathrm{~g} ; p<$ 0.001) (Fig. 1).)

Effects of early life dietary protein restriction on spontaneous pulsatile $\mathrm{GH}$ secretion and basal plasma IGF-I levels in adulthood. Normally fed adult animals exhibited the typical pulsatile pattern of $\mathrm{GH}$ secretion characteristic of the male rat (Fig. 2A). Two major episodes of $\mathrm{GH}$ secretion were observed during the 6-h sampling period with most individual peak $\mathrm{GH}$ values greater than $150 \mu \mathrm{g} / \mathrm{L}$; in the intervening trough periods, plasma $\mathrm{GH}$ values were usually below $1.2 \mu \mathrm{g} / \mathrm{L}$. Adult rats fed the $4 \%$ protein diet between 3 and 6 wk of age continued to show the pulsatile pattern of GH release; however, the amplitude of the spontaneous GH pulses was decreased in these animals compared with normal diet-fed controls (Fig. 2B).

Cluster analysis of GH secretory dynamics (Fig. 3) revealed a $41 \%$ reduction in mean $\mathrm{GH}$ peak amplitude $(197.3 \pm 67.1$ versus $335.4 \pm 79.4 \mu \mathrm{g} / \mathrm{L}$ ) and a significant suppression in

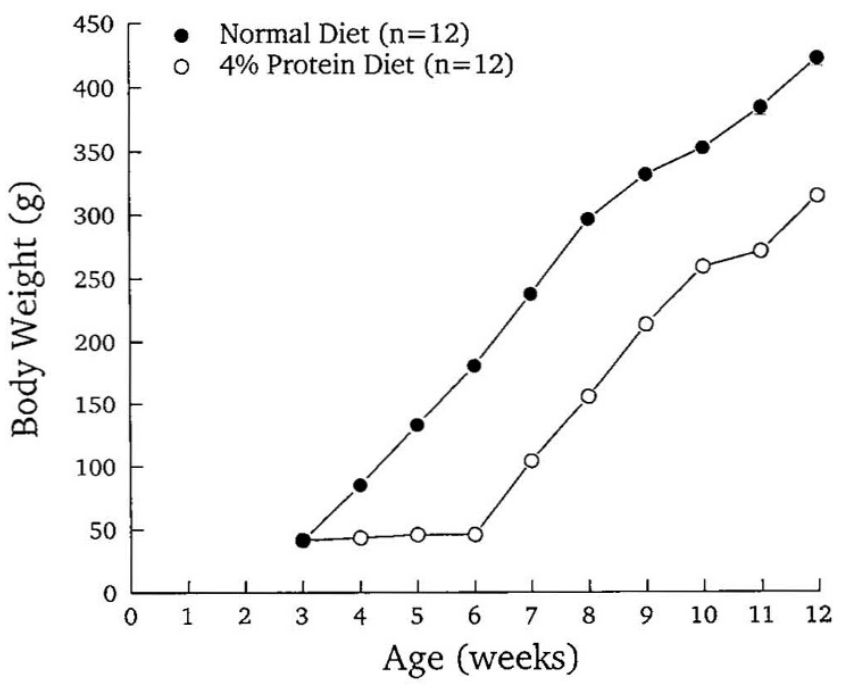

Figure 1. Growth curves of rats fed the $4 \%$ protein diet (open circles) or the normal diet (closed circles) between 3 and $6 \mathrm{wk}$ of age. From 6 to $12 \mathrm{wk}$ of age, both groups were maintained on the normal diet. Values are the mean \pm $\mathrm{SE}$; the SE are within the area of the symbols. The number of rats in each group is shown in parentheses. 


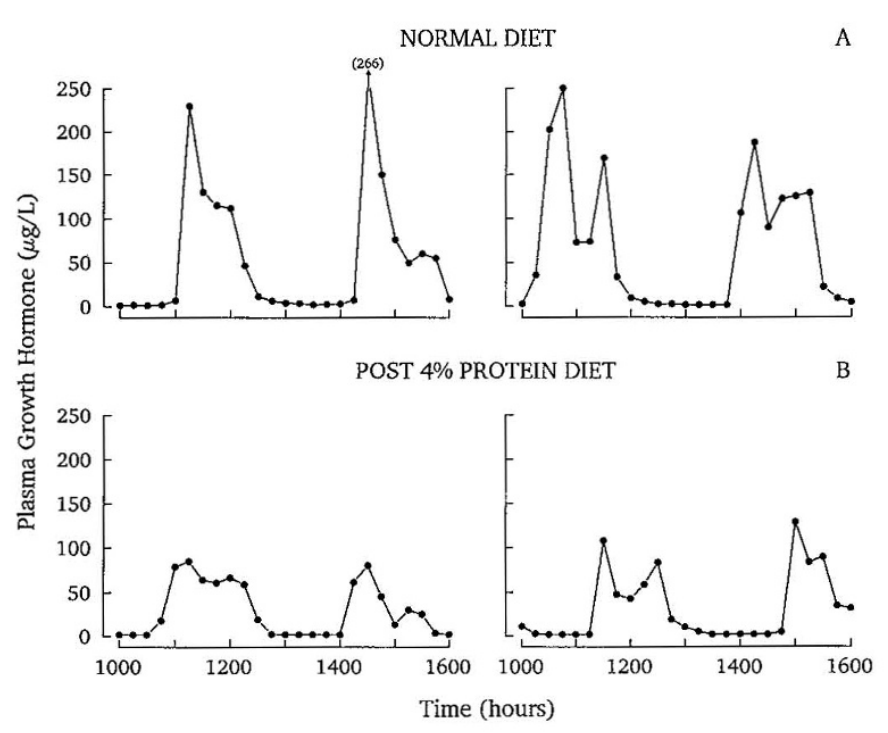

Figure 2. Individual representative 6-h plasma $\mathrm{GH}$ profiles in two adult rats fed the normal diet $(A)$ compared with those in adult rats fed the $4 \%$ protein diet between 3 and $6 \mathrm{wk}$ of age $(B)$. Rats exposed to dietary protein restriction in early life exhibited an attenuation in amplitude of the spontaneous GH secretory bursts, although the typical ultradian rhythm of $\mathrm{GH}$ secretion was preserved.

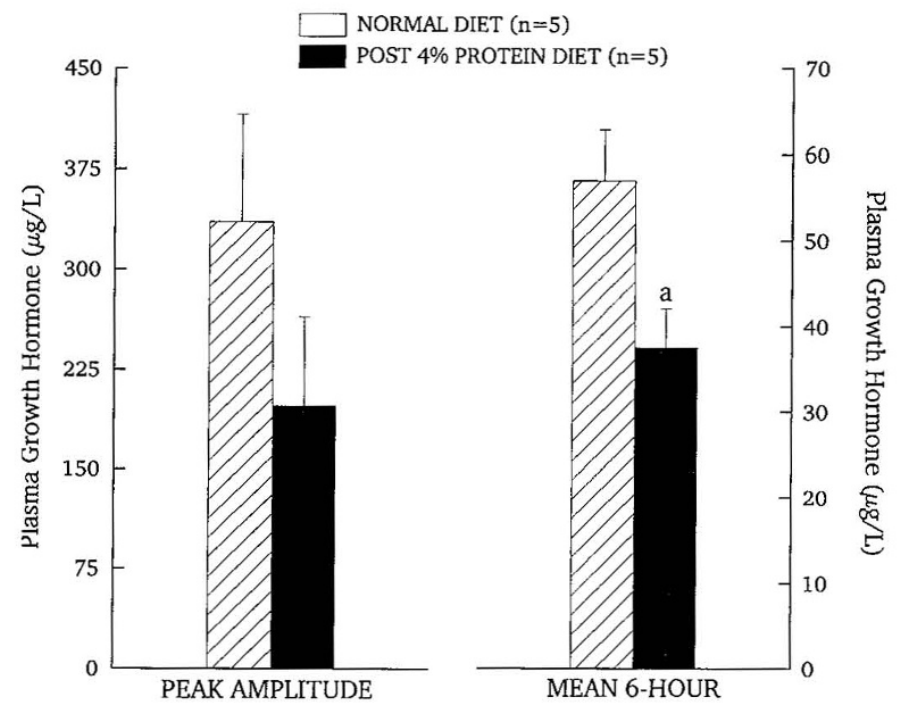

Figure 3. Cluster analysis of effects of dietary protein restriction early in life on pulsatile $\mathrm{GH}$ secretion. Rats fed the $4 \%$ protein diet between 3 and 6 wk of age exhibited a reduction in $\mathrm{GH}$ peak amplitude and overall mean 6-h plasma $\mathrm{GH}$ levels in adulthood. Each bar represents the mean \pm SE. The number of animals in each group is shown in parentheses. $a, p<0.02$ compared with normally fed rats.

overall mean 6-h plasma GH levels $(37.5 \pm 4.5$ versus $56.9 \pm$ $5.9 \mu \mathrm{g} / \mathrm{L} ; p<0.02)$ in rats fed the low protein diet compared with control-fed rats. There were no significant differences in $\mathrm{GH}$ trough levels within the limits of detection of our GH RIA $(1.2 \pm 0$ versus $1.2 \pm 0.02 \mu \mathrm{g} / \mathrm{L})$, or in interpeak interval $(3.7$ \pm 0.9 versus $2.8 \pm 0.4 \mathrm{~h}$ ), suggesting that the normal pulsatile pattern of $\mathrm{GH}$ secretion was preserved in these animals despite the attenuation in overall $\mathrm{GH}$ release.

Although the basal (at $1000 \mathrm{~h}$ ) levels of plasma IGF-I in adult rats subjected to early life dietary protein restriction $(680$ $\pm 60 \mu \mathrm{g} / \mathrm{L}$ ) were lower than those observed in rats fed the normal diet $(770 \pm 40 \mu \mathrm{g} / \mathrm{L})$, the difference did not reach statistical significance $(p>0.20)$.

Long-term effects of early life exposure to $4 \%$ protein diet on $\boldsymbol{G H}$ responsiveness to $\boldsymbol{G R F}$. Figure 4 illustrates the mean $\mathrm{GH}$ response to GRF administered at 1100 and $1300 \mathrm{~h}$ in both groups of rats. Animals fed the normal diet exhibited the typical malelike time-dependent pattern of $\mathrm{GH}$ responsiveness to GRF (18), with high GRF-induced GH release observed at the time of a spontaneous $\mathrm{GH}$ peak $(564.6 \pm 91.6 \mu \mathrm{g} / \mathrm{L})$ and only a limited response during the trough period $(43.9 \pm 17.6$ $\mu \mathrm{g} / \mathrm{L} ; p<0.02$ ) (Fig. $4 A$ ). Although adult rats fed the $4 \%$ protein diet between 3 and $6 \mathrm{wk}$ of age continued to exhibit a time-dependent difference in their ability to respond to GRF $(646.6 \pm 79.8$ versus $165.6 \pm 30.4 \mu \mathrm{g} / \mathrm{L} ; p<0.02)$, the magnitude of their $\mathrm{GH}$ response during the trough period was augmented when compared with GRF-induced GH release in control-fed rats at the same time points (Fig. $4 B$ ).

Figure 5 summarizes the pituitary $\mathrm{GH}$ responsiveness to GRF in the two groups of rats. Compared with rats fed the normal diet, $4 \%$ protein-fed rats released 3-4-fold more $\mathrm{GH}$ at $1300 \mathrm{~h}(165.7 \pm 30.4$ versus $43.9 \pm 17.6 \mu \mathrm{g} / \mathrm{L} ; p<0.01)$. Although GRF-induced GH release in these rats was also higher at $1100 \mathrm{~h}(646.6 \pm 79.8$ versus $564.6 \pm 91.6 \mu \mathrm{g} / \mathrm{L})$, this difference did not reach significance.

Effects of dietary protein restriction in early life on glucose tolerance and insulin secretory response to glucose in adulthood. The adult basal fasting levels of glucose $(6.3 \pm 0.3$ $\mathrm{mmol} / \mathrm{L})$ and insulin $(55.1 \pm 0 \mathrm{pmol} / \mathrm{L})$ in those rats subjected to early life dietary protein restriction were similar to the basal levels of glucose $(6.3 \pm 0.1 \mathrm{mmol} / \mathrm{L})$ and insulin $(58.5 \pm 3.4$ $\mathrm{pmol} / \mathrm{L}$ ) observed in the control group fed the normal diet (Fig. $6)$. After the glucose challenge, plasma glucose values increased to a peak of $29.0 \pm 1.0 \mathrm{mmol} / \mathrm{L}$ in the low protein-fed group which did not differ from the peak glucose response

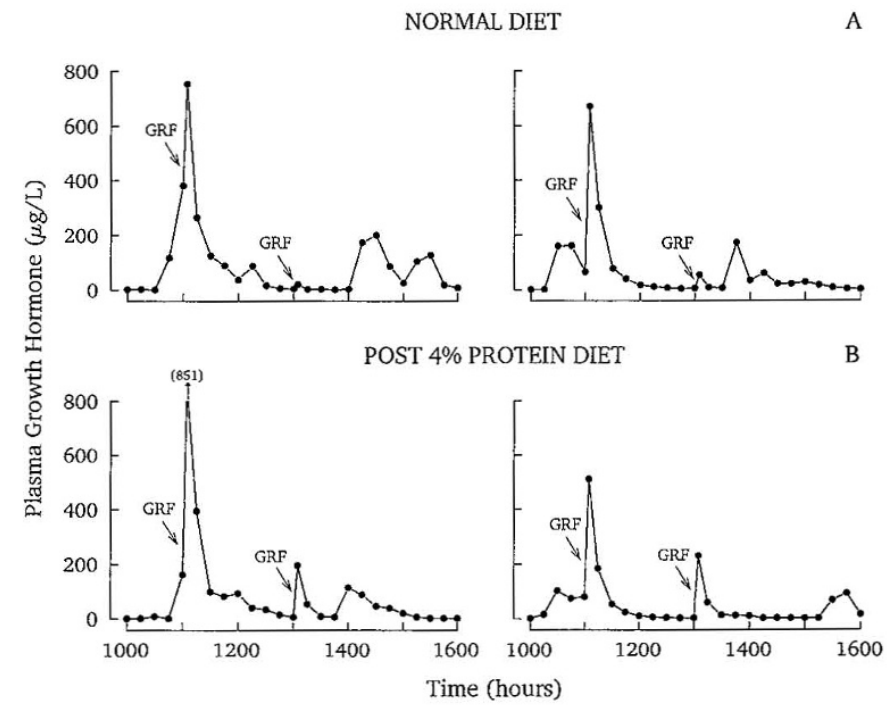

Figure 4. Adult plasma GH responses to $1 \mu \mathrm{g}$ of GRF administered during peak $(1100 \mathrm{~h})$ and trough $(1300 \mathrm{~h})$ periods of $\mathrm{GH}$ secretion in individual rats fed either the normal diet $(A)$ or the $4 \%$ protein diet $(B)$ during 3-6 wk of age. The magnitude of the $\mathrm{GH}$ response to GRF challenge was augmented at trough times in rats fed the low protein diet. Arrows indicate the times of i.v. injections. 


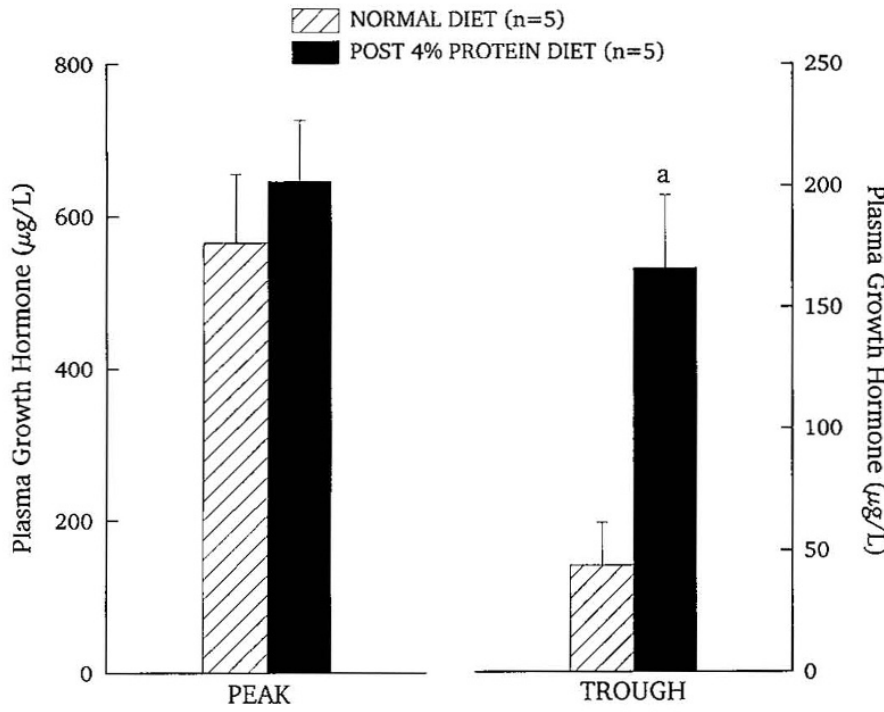

Figure 5. Summary of GH responsiveness to GRF in normal diet-fed rats and adult rats subjected to temporary dietary protein restriction early in life. Both groups exhibited a time-dependent difference in their ability to respond to GRF, with GRF-induced GH release being significantly greater during a time of peak $\mathrm{GH}$ secretion than during a trough period. However, rats fed the $4 \%$ diet showed a 3-4-fold augmentation in GH responsiveness to GRF at trough times compared with normally fed controls. Each bar represents the mean \pm SE. The number of animals in each group is shown in parentheses. $a, p<0.01$ compared with $\mathrm{GH}$ release during trough periods in rats fed the normal diet.

observed in the control group $26.9 \pm 1.5 \mathrm{mmol} / \mathrm{L}$ (Fig. $6 A$ ). Subsequently, plasma glucose levels declined rapidly in both groups to values which again were not significantly different from each other. There was no significant difference in the integrated area under the glucose response curve between the two groups $(19.1 \pm 0.8$ versus $18.6 \pm 1.4 \mathrm{mmol} / \mathrm{L} / 75 \mathrm{~min})$.

In contrast to the normal glucose tolerance, the insulin response to intraperitoneal glucose was markedly blunted at $15,30,45$, and $60 \mathrm{~min}$ in those rats fed the $4 \%$ protein diet in early life, when compared with rats fed the normal diet (Fig. 6B). The integrated area under the insulin response curve (AUC) in these animals was 2-3-fold lower than that of normally fed controls (AUC over 75 $\min$ : $303.0 \pm 32.7$ versus $778.3 \pm 105.0 \mathrm{pmol} / \mathrm{L} / 75 \mathrm{~min} ; p<$ $0.01)$. Moreover, whereas control-fed animals showed a second smaller insulin secretory response at 105-135 min after the intraperitoneal glucose injection, this was absent in rats fed the $4 \%$ protein diet in early life (see Fig. $6 B$ ).

Pituitary wet weight and pituitary GH concentration in rats fed the $4 \%$ protein diet in early life. The pituitary wet weight $(11.3 \pm 0.4$ versus $14.1 \pm 0.7 \mathrm{mg} ; p<0.01)$ and pituitary $\mathrm{GH}$ content $(520.5 \pm 41.7$ versus $631.8 \pm 48.2 \mu \mathrm{g} /$ fragment; NS) of rats exposed to the $4 \%$ protein diet early in life were lower than those of normal diet-fed rats. However, when expressed in relation to body and organ weights, respectively, the relative pituitary wet weight $(3.5 \pm 0.1$ versus $3.3 \pm 0.1 \mathrm{mg} / 100 \mathrm{~g}$ of body weight) and pituitary $\mathrm{GH}$ concentration $(46.2 \pm 3.7$ versus $44.6 \pm 3.0 \mu \mathrm{g} / \mathrm{mg}$ of wet weight) in $4 \%$ protein-fed rats were similar to those in rats fed the normal diet.

Pancreatic immunoreactive somatostatin and insulin concentration in adult rats exposed to dietary protein restriction in early life. Both pancreatic SLI $(0.21 \pm 0.03$ versus $0.18 \pm$ $0.03 \mathrm{ng} / \mathrm{mg}$ of wet weight $)$ and IRI $(12.5 \pm 3.2$ versus $9.0 \pm$
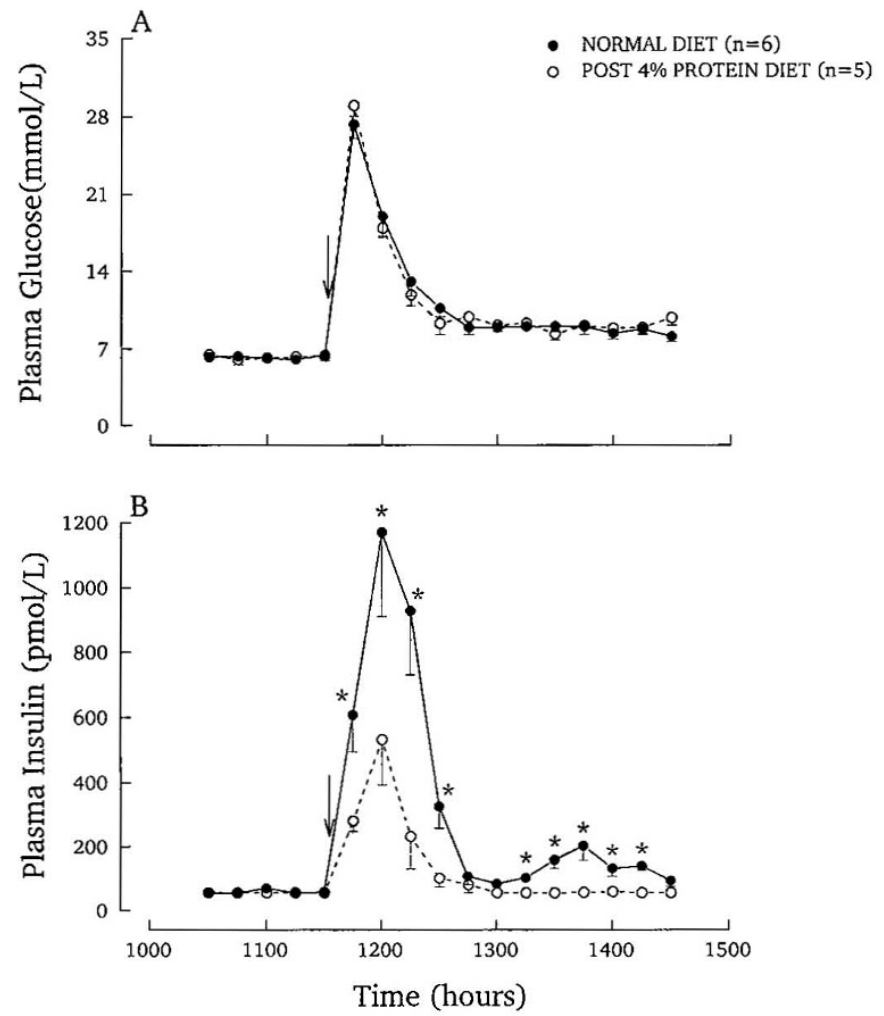

Figure 6. Mean plasma glucose $(A)$ and insulin $(B)$ response to ip glucose challenge ( $2 \mathrm{~g} / \mathrm{kg}$ of body weight) at 12 wk of age in rats fed either the $4 \%$ protein diet (dashed line) or the normal diet (solid line) during 3-6 wk of age. Although the glucose response was similar in both groups, protein malnutrition early in life resulted in a severe impairment of the insulin secretory response to glucose in adulthood. Arrows indicate the time of injection. Vertical lines indicate the SE. The number of rats in each group is shown in parentheses. ${ }^{*} p$ $<0.05$ or less $v s$ normally fed rats.

$3.7 \mathrm{ng} / \mathrm{mg}$ of wet weight) concentrations were not different in adult rats exposed to the $4 \%$ protein diet early in life when compared with those of normally fed control animals.

\section{DISCUSSION}

The results of the present study demonstrate that temporary dietary protein malnutrition early in life leads to persisting alterations in GH and insulin secretion, which likely contribute to the lack of catch-up growth observed in this model.

Rats weaned onto a low (4\%) protein diet between 3 and 6 wk of age exhibited a reduction in $\mathrm{GH}$ peak amplitude and mean 6-h plasma GH concentrations at 12 wk of age when compared with rats weaned onto a normal diet (23\% protein). Despite this attenuation in overall GH release, the normal ultradian rhythm of GH secretion was preserved in these animals. These findings extend our earlier observations in the adult rat that short-term dietary protein restriction impairs pulsatile GH secretion (16).

The size of the pituitary gland was significantly lower in adult rats subjected to temporary protein restriction early in life than in normally fed controls. Although pituitary GH content was also lower in the adult rats weaned onto the $4 \%$ protein diet, when expressed in relation to body and organ weight, respectively, both pituitary wet weight and GH concentrations were similar in the two groups. These data indicate a relatively 
preserved pituitary $\mathrm{GH}$ pool, and suggest that the pituitary gland might recover from the general cellular hypoplasia induced by limited protein-energy malnutrition early in life (5). It remains to be determined whether there are permanent changes in somatotroph number and/or somatotroph cell size after temporary early life dietary protein restriction.

The secretion of $\mathrm{GH}$ from the pituitary is regulated by a delicate interplay between stimulatory (GRF) and inhibitory (SRIF) hypothalamic hormones (18). In the present study, adult rats subjected to temporary early life protein restriction exhibited a 3-4-fold augmentation in $\mathrm{GH}$ responsiveness to GRF challenge, at trough times, when compared with that of normal diet-fed rats. Both SRIF and GRF have been shown to be sensitive to changes in nutritional status $(21,22,24,25)$. In particular, Bruno et al. (25) reported a dramatic reduction in hypothalamic preproGRF mRNA levels in protein-deprived adult rats. It is therefore possible that early postnatal protein deprivation produced a long-term alteration in hypothalamic GRF gene expression and/or release. A reduction in hypothalamic GRF signaling to pituitary somatotrophs could conceivably alter GRF receptor sensitivity resulting in up-regulation of the somatotroph GRF receptor, and perhaps account for both the augmentation in $\mathrm{GH}$ responsiveness to GRF and the attenuation in spontaneous $\mathrm{GH}$ pulses that we observed.

The augmented GH responsiveness to GRF reported here differs from our earlier observation of diminished GRFinduced $\mathrm{GH}$ release in rats fed a low protein diet in adult life (16), but resembles the paradoxical enhancement of $\mathrm{GH}$ responsiveness to GRF found in food-deprived adult rats that exhibit high SRIF tone (26). Thus, an increased SRIF influence on pituitary somatotrophs could provide an additional explanation for the suppression in GH pulse amplitude and the enhanced GH response to GRF that we observed in adult rats exposed to protein deprivation in early life. On the other hand, an increase in GRF-induced GH release at GH trough times has also been found in rats passively immunized with anti-SRIF serum (18). Thus, it remains unclear whether the somatostatinergic system is altered in this model.

It is also possible that the lack of essential amino acid dietary components early in life altered other brain neurotransmitters which are known to modulate $\mathrm{GH}$ secretion via changes in hypothalamic SRIF and/or GRF (27). Protein deprivation during development has been shown to significantly affect a variety of neurotransmitter systems including $\beta$-endorphin ( 8 , 28 ); this could provide another mechanism for the alteration in the GH neuroendocrine axis. Although the hypothalamichypophysial axis is evident by the eighth postnatal day in the rat (29), CNS control of GH does not mature until after puberty (30). Taken together, all of these findings suggest that the maturation process of the regulatory mechanisms governing $\mathrm{GH}$ secretion is dependent upon adequate dietary protein supply during early life.

At the level of the pancreas, experimental protein-calorie malnutrition has been shown to reduce both the size of the individual $\beta$-cell (31) and the total islet mass (32). It is believed that the persistent reduction of pancreatic $\beta$-cell mass (11) results in an inadequate insulin secretory response to glucose (5), which may impair the ability of the $\beta$-cells to withstand an environmental diabetogenic insult (33). Our finding of a significant decrease in both the rapid first phase and second phase insulin secretory response to glucose, in the face of normal pancreatic insulin concentrations, suggests an altered sensitivity of the $\beta$-cell to glucose in adult rats exposed to temporary dietary restriction early in life. These in vivo results are similar to those previously reported by Swenne et al. (34) in vitro, and confirm that dietary protein during the weaning period is an important determinant for the development of $\beta$-cell sensitivity to glucose in the rat.

The presence of a normal glucose tolerance, despite the low insulin response to glucose, indicates that sufficient insulin was secreted for metabolic needs in the protein-deprived animals, and is consistent with the findings of Escriva et al. (12) of an increased sensitivity to insulin in target tissues of adult rats subjected to temporary early life protein malnutrition. Inasmuch as $\mathrm{GH}$ is known to induce a peripheral resistance to insulin action (13), it is conceivable that the relative deficiency of $\mathrm{GH}$ release, shown in this animal model for the first time, provides a compensatory mechanism to enhance peripheral tissue sensitivity to insulin in these rats. The finding of normal pancreatic SRIF concentration in these rats suggests that intrapancreatic SRIF is not involved in this response.

The mechanism(s) whereby protein malnutrition early in life stunts subsequent physical growth is, as yet, unknown. In the present study, rats subjected to dietary protein restriction from weaning to $6 \mathrm{wk}$ of age failed to catch-up growth when transferred to the normal diet between 6-12 wk of age. This contrasts with findings in adult rats which exhibit catch-up growth (and increased GH concentrations) after exposure to a short period (24-72 h) of fasting (35). Increased insulin secretion has been considered to be one of the mechanisms responsible for catch-up growth during recovery from either acute starvation (36) or acute infection in weanling rats (37). In the experiments reported here, the amount of insulin appears to have been sufficient for glucose homeostasis, but was clearly insufficient to induce catch-up growth during the 6-12-wk time period. It has been shown that insulin plays a role in regulating GH-binding sites in peripheral tissues (38), in addition to the known regulatory role of $\mathrm{GH}$ (39), and that protein-deprived adult rats which are hypoinsulinemic $(16,40)$ have a reduced number of peripheral GH-binding sites (41). Therefore, it is plausible that the relative deficiency of $\mathrm{GH}$ secretion observed in the present study, together with the persisting reduction in insulin secretion, results in a decrease in GH-binding sites in peripheral tissues and, as a consequence, these tissues lack the ability to increase IGF-I production to the supranormal levels associated with compensatory (42) or catch-up growth. Indeed, plasma IGF-I levels in the adult rats subjected to temporary early life protein-energy malnutrition in the present study failed to exceed normal levels, consistent with that previously reported for both tissue and serum IGF-I concentrations in this model (15). All of these findings suggest that the cooperative interaction between $\mathrm{GH}$, insulin, and IGF-I, which is essential for the normal growth process, is altered in this model.

In conclusion, the results of the present study demonstrate that temporary dietary protein restriction early in life 1 ) blunts spontaneous pulsatile $\mathrm{GH}$ secretion, 2) augments $\mathrm{GH}$ respon- 
siveness to GRF challenge, and 3) reduces the insulin secretory response to glucose in adulthood. Our findings suggest that dietary protein in early life is an important determinant for $\mathrm{CNS}$ control of GH secretion as well as for the development of pancreatic $\beta$-cell sensitivity to glucose. Such alterations in the $\mathrm{GH}$ neuroendocrine axis, together with the subnormal insulin secretion, likely contribute to the lack of catch-up growth after temporary dietary protein restriction early in life.

Acknowledgments. The authors thank Martine Lapointe and Wendy Gurd for skillful technical assistance and Julie Temko for expert secretarial help. We are grateful to Dr. R. Chance for the gift of rat insulin and Dr. P. Brazeau for the gift of the GRF peptide. The generous supply of GH and IGF-I RIA materials from the National Institute of Diabetes and Digestive and Kidney Diseases is gratefully acknowledged.

\section{REFERENCES}

1. Stoch MB, Smythe PM 1976 15-year developmental study on effects of severe undernutrition during infancy on subsequent physical growth and intellectual functioning. Arch Dis Child 51:327-336

2. Kulin HE, Bwibo N, Mutie D, Med M, Santner SJ 1982 The effect of chronic childhood malnutrition on pubertal growth and development. Am J Clin Nutr 36:527536

3. Galler JR, Ramsey F, Solimano G 1985 A follow-up study of the effects of early malnutrition on subsequent development. I. Physical growth and sexual maturation during adolescence. Pediatr Res 19:518-523

4. Galler JR, Ramsey FC, Salt P, Archer E 1987 Long-term effects of early kwashiorkor compared with marasmus. I. Physical growth and sexual maturation. J Pediat Gastroenterol Nutr 6:841-846

5. Swenne I, Crace CJ, Milner RDG 1987 Persistent impairment of insulin secretory response to glucose in adult rats after limited period of protein-calorie malnutrition early in life. Diabetes 36:454-458

6. Morgan BLG, Naismith DJ 1982 The effect of early postnatal undernutrition on the growth and development of the rat brain. Br J Nutr 48:15-23

7. Syme G 1982 The effect of protein-deficient isoenergetic diets on the growth of rat jejunal mucosa. Br J Nutr 48:25-36

8. Wiggins RC, Fuller G, Enna SJ 1984 Undernutrition and the development of brain neurotransmitter systems. Life Sci 35:2085-2094

9. Glore SR, Layman DK 1987 Cellular development of skeletal muscle of rats during recovery from prolonged undernutrition. J Nutr 117:1767-1774

10. Winick M 1987 Long term effects of kwashiorkor. J Pediatr Gastroenterol Nutr 6:833-840

11. Swenne I, Borg LAH, Crace CJ, Schnell Landstrom A 1992 Persistent reduction of pancreatic beta-cell mass after a limited period of protein-energy malnutrition in the young rat. Diabetologia 35:939-945

12. Escriva F, Kergoat M, Bailbe D, Pascual-Leone AM, Portha B 1991 Increased insulin action in the rat after protein malnutrition early in life. Diabetologia 34:559-564

13. Caprio S, Boulware D, Tamborlane V 1992 Growth hormone and insulin interactions. Horm Res 38(suppl 2):47-49

14. Moller N, Jorgensen JOL, Abildgård N, Ørskov L, Schmitz O, Christiansen JS 1991 Effects of growth hormone on glucose metabolism. Horm Res 36(suppl 1):32-35

15. Crace CJ, Swenne I, Hill DJ, Milner RDG 1991 Tissue and serum insulin-like growth factor I (IGF I) concentrations in rats subjected to temporary protein-energy malnutrition early in life. Upsala J Med Sci 96:17-22

16. Harel Z, Tannenbaum GS 1993 Dietary protein restriction impairs both spontaneous and growth hormone-releasing factor-stimulated growth hormone release in the rat. Endocrinology 133:1035-1043
17. Tannenbaum GS, Martin JB 1976 Evidence for an endogenous ultradian rhythm governing growth hormone secretion in the rat. Endocrinology 98:562-570

18. Tannenbaum GS, Ling $\mathrm{N} 1984$ The interrelationship of growth hormone (GH)releasing factor and somatostatin in generation of the ultradian rhythm of $\mathrm{GH}$ secretion. Endocrinology 115:1952-1957

19. Daughaday WH, Kapadia M, Mariz I 1987 Serum somatomedin binding proteins: physiologic significance and interference in radioligand assay. J Lab Clin Med 109:355-363

20. Breier BH, Gallagher BW, Gluckman PD 1991 Radioimmunoassay for insulin-like growth factor-I: solutions to some potential problems and pitfalls. J Endocrinol 128:347-357

21. Tannenbaum GS, Epelbaum J, Colle E, Brazeau P, Martin JB 1978 Antiserum to somatostatin reverses starvation-induced inhibition of growth hormone but not insulin secretion. Endocrinology 102:1909-1914

22. Tannenbaum GS, Rorstad O, Brazeau P 1979 Effects of prolonged food deprivation on the ultradian growth hormone rhythm and immunoreactive somatostatin tissue levels in the rat. Endocrinology 104:1733-1738

23. Veldhuis JD, Johnson ML 1986 Cluster analysis: a simple versatile, and robust algorithm for endocrine pulse detection. Am J Physiol 250:E486-E493

24. Bruno JF, Olchovsky D, White JD, Leidy JW, Song J, Berelowitz M 1990 Influence of food deprivation in the rat on hypothalamic expression of growth hormonereleasing factor and somatostatin. Endocrinology 127:2111-2116

25. Bruno JF, Song J, Berelowitz M 1991 Regulation of rat hypothalamic preprogrowth hormone-releasing factor messenger ribonucleic acid by dietary protein. Endocrinology 129:1226-1232

26. Tannenbaum GS, Painson J-C, Lengyel AMJ, Brazeau P 1989 Paradoxical enhancement of pituitary growth hormone $(\mathrm{GH})$ responsiveness to $\mathrm{GH}$-releasing factor in the face of high somatostatin tone. Endocrinology 124:1380-1388

27. Dieguez C, Page MD, Scanlon MF 1988 Growth hormone neuroregulation and its alterations in disease states. Clin Endocrinol 28:109-143

28. Vendite D, Rocha JBT, Souza DO 1988 Effects of undernutrition during suckling and of training on the hypothalamic $\beta$-endorphin of young and adult rats. Peptides 9:751-755

29. Fink G, Smith GC 1971 Ultrastructural features of the developing hypothalamohypophysial axis in the rat. Z Zellforsch Mikrosk Anat 119:208-226

30. Kuhn CM, Schanberg SM 1981 Maturation of central nervous system control of growth hormone secretion in rats. J Pharmacol Exp Ther 217:152-156

31. Platt BS, Stewart RJC 1967 Experimental protein-calorie deficiency: histopathological changes in the endocrine glands of pigs. J Endocrinol 38:121-143

32. Weinkove C, Weinkove E, Timme A, Pimstone B 1977 Pancreatic islets of malnourished rats. Quantitative histologic and electron microscopic findings. Arch Pathol Lab Med 101:266-269

33. Rao RH 1988 Diabetes in the undernourished: coincidence or consequence? Endocr Rev 9:67-87

34. Swenne I, Crace CJ, Jansson L 1988 Intermittent protein-calorie malnutrition in the young rat causes long-term impairment of the insulin secretory response to glucose in vitro. J Endocrinol 118:295-302

35. Mosier Jr HD, Jansons RA, Dearden LC 1985 Increased secretion of growth hormone in rats undergoing catch-up growth after fasting. Growth 49:346-353

36. Garlick PJ, Fern M, Preedy VR 1983 The effect of insulin infusion and food intake on muscle protein synthesis in postabsorptive rats. Biochem J 210:669-676

37. Samuels SE, Baracos VE 1992 Catch-up growth following Escherichia coli infection in weanling rats. Metabolism 41:208-215

38. Baxter RC, Bryson JM, Turtle JR 1980 Somatogenic receptors of rat liver: regulation by insulin. Endocrinology 107:1176-1181

39. Grichting G, Goodman HM 1986 Growth hormone maintains its own receptors in rat adipocytes. Endocrinology 119:847-854

40. Okitolonda W, Brichard SM, Henquin JC 1987 Repercussions of chronic proteincalorie malnutrition on glucose homeostasis in the rat. Diabetologia 30:946-951

41. Maiter D, Maes M, Underwood LE, Fliesen T, Gerard G, Ketelslegers J-M 1988 Early changes in serum concentrations of somatomedin- $\mathrm{C}$ induced by dietary protein deprivation in rats: contributions of growth hormone receptor and post-receptor defects. J Endocrinol 118:113--120

42. El Nahas AM, Le Carpentier JE, Bassett AH, Hill DJ 1989 Dietary protein and insulin-like growth factor-I content following unilateral nephrectomy. Kidney Int 36(suppl 27):S15-S19 